\title{
Characterization and Regional Distribution of Glutamatergic and Cholinergic Ligand Binding Sites in Goldfish Brain
}

\author{
Jeremy M. Henley a and Robert E. Oswald \\ Department of Pharmacology, New York State College of Veterinary Medicine, Cornell University, Ithaca, New York 14850
}

The binding of several ligands that selectively interact with glutamate receptor subtypes was characterized in extensively washed synaptosomal membrane preparations from goldfish brain. The binding affinity $\left(K_{d}\right)$, an estimate of the number of sites $\left(B_{\max }\right)$, the rank-order potency of glutamatergic ligands at inhibiting binding, and the regional localization of binding sites were determined. In whole brain preparations, ${ }^{3} \mathrm{H}$-kainate had a $K_{\mathrm{d}}$ of $136 \mathrm{~nm}$ and a $B_{\max }$ of $63 \mathrm{pmol} /$ mg protein, ${ }^{3} \mathrm{H}-\mathrm{AMPA}$ had a $K_{\mathrm{d}}$ of $26 \mathrm{nM}$ and a $B_{\max }$ of 0.4 $\mathrm{pmol} / \mathrm{mg}$ protein, and ${ }^{3} \mathrm{H}-\mathrm{L}-\mathrm{glutamate}$ bound with an apparent affinity of $323 \mathrm{nM}$ and $a B_{\max }$ of $5 \mathrm{pmol} / \mathrm{mg}$ protein. Most of the binding sites for each of the glutamate analogs were present in the cortex and the fewest were in the cerebellum, except for ${ }^{3} \mathrm{H}-k a i n a t e$ binding sites, which were most prevalent in the cerebellum and least abundant in the cortex. The proposed neuronal nicotinic acetylcholine receptor (nAChR) ligands ${ }^{3} \mathrm{H}-(-)$ nicotine and ${ }^{125} \mathrm{I}-\alpha$-Bgt were also investigated. ${ }^{125} \mathrm{I}-\alpha$-Bgt had a $K_{\mathrm{d}}$ of $0.08 \mathrm{nM}$ and a $B_{\max }$ of $132 \mathrm{fmol} / \mathrm{mg}$ protein. ${ }^{3} \mathrm{H}-(-)$ nicotine did not bind to the extensively washed membrane preparations, so a less stringently washed P2 tissue fraction was used. In this tissue preparation, ${ }^{3} \mathrm{H}-$ $\left(-\right.$ )nicotine had a $K_{\mathrm{d}}$ of $9 \mathrm{nM}$ and a $B_{\max }$ of $84 \mathrm{fmol} / \mathrm{mg}$ protein. Eye removal resulted in a time-dependent decrease in the number of ${ }^{3} \mathrm{H}-(-)$ nicotine and ${ }^{125} \mathrm{I}-\alpha$-Bgt binding sites in the contralateral optic tectum, but no reduction in the number of binding sites for any of the glutamatergic ligands. The results suggest that both ${ }^{3} \mathrm{H}-(-)$ nicotine and ${ }^{125} \mid-\alpha$-Bgt binding sites are similarly regulated in the optic tectum, which supports previously reported data indicating that the binding sites are located on closely related proteins or may, at least partially, be colocalized on the same protein (Henley and Oswald, 1987). The data for glutamatergic ligands do not preclude a role for glutamatergic receptors in the retinotectal system of goldfish, but indicate that the receptor numbers are not regulated by removal of visually evoked neuronal stimulation.

L-Glutamate has been proposed as a major neurotransmitter in the vertebrate CNS (reviewed by Foster and Fagg, 1984; Mayer

\footnotetext{
Received July 7, 1987; accepted Oct. 30, 1987

We are grateful to Dr. Linda Nowak for advice and the kind gift of a number of glutamatergic agonists and antagonists. We also thank Dr. Glenn Millhauser for his help in analyzing the data. This work was supported by grants from the Sloan Foundation and the National Science Foundation (BNS 82-14287) to R.E.O.

Correspondence should be addressed to Robert E. Oswald at the above address

a Present address: MRC Molecular Neurobiolngy Unit, Medical School, Hills Road, Cambridge CB2 2QH, England.

Copyright (C) 1988 Society for Neuroscience $0270-6474 / 88 / 062101-07 \$ 02.00 / 0$
}

and Westbrook, 1987). Glutamate receptors have been most extensively investigated using electrophysiological techniques, and L-glutamate-evoked depolarizations appcar to be mediatcd via at least 3 receptor subtypes, namely, $N$-methyl-D-aspartate (NMDA)-selective, quisqualate-selective, and kainate-selective (Watkins and Evans, 1981). Considerable electrophysiological evidence from NMDA antagonist studies suggests that at least the NMDA receptor is involved in synaptic transmission and can be modulated by phencyclidine (Snell and Johnson, 1985). NMDA antagonists can block some dorsal root-evoked ventral root responses (Davies and Watkins, 1983), can prevent the generation of long-term potentiation in the hippocampus (Collingridge et al., 1983), and can antagonize some EPSP responses in the hippocampus and cerebral cortex (Thomson et al., 1985).

In addition to electrophysiological studies, as specific radiolabeled agonists and antagonists become available, ligand-binding procedures are being increasingly used to investigate quantitatively glutamatergic receptor subtype distribution and pharmacology (for review, see Foster and Fagg, 1984). In general, the results from radioligand binding studies agree well with electrophysiological data. The excitatory actions of NMDA, quisqualate, and kainate each appears to be associated with proteins with distinct pharmacological specificities. The involvement of each of these distinct binding sites in physiological synaptic excitation, however, remains to be determined.

One neuronal pathway in which glutamatergic receptors may play an important role is the vertebrate visual system. Although a number of putative neurotransmitte substances have been proposed, in particular L-glutamate and $\mathrm{ACh}$, the identity of the primary neurotransmitter in the visual system of vertebrates remains unclear.

The presence of nicotinic acetylcholine receptors ( $\mathrm{AChRs}$ ) in the layers of the tectum that receive input from the retina has been well established in the lower vertebrates goldfish, frog, and toad. The snake venom component $\alpha$-bungarotoxin ( $\alpha$-Bgt), which binds with high specificity and affinity to $\mathrm{AChRs}$ present in the vertebrate neuromuscular junction and in the electroplaque of electric fish, inhibits visually evoked field potentials in the goldfish optic tectum (Freeman et al., 1980; Schmidt and Freeman, 1980). $\alpha$-Bgt and anti-nAChR polyclonal antibody binding sites are lost from the contralateral tectum following eye removal (Schecter et al., 1979; Oswald et al., 1980; Schwartz et al., 1980; Henley et al., 1986a) and there is some evidence to suggest that there is a reduction in the number of (-)nicotine binding sites in the contralateral tectum following enucleation (Henley and Oswald, 1987). These data have been interpreted by some workers to suggest that $\mathrm{ACh}$ may be the retinotectal neurotransmitter. 
Evidence using a monoclonal antibody raised against the Electrophorus electroplaque nAChR and ${ }^{35}$ S-methionine biosynthetic incorporation techniques has recently suggested that, in goldfish, the nAChRs may be localized on the presynaptic terminals of the retinotectal projection rather than on the postsynaptic density (Henley et al., 1986b). These data suggest that ACh may not be the primary neurotransmitter in the retinotectal system. Gruberg and coworkers have suggested that the presynaptic nAChRs may be part of a neural projection linking the optic tectum with the nucleus isthmus and that this projection may play a modulatory role in retinotectal transmission (Ricciuti and Gruberg, 1985).

The other frequently proposed primary neurotransmitter candidate in this system is L-glutamate, which, as briefly outlined above, has been shown to act as an excitatory neurotransmitter in various species and in a number of CNS areas. The optic tectum of pigeon has been shown to contain high levels of endogenous glutamate (Beart, 1976), iontophoretic application of L-glutamate excites a large proportion of the tectal neurons (Barth and Felix, 1974), and the high-affinity L-glutamate-uptake system in both frog (Roberts and Yates, 1976) and pigeon (Henke et al., 1976) optic tectum has been reported to be reduced following eye removal. More recently, field potentials recorded from isolated sections of goldfish optic tectum have demonstrated that many nicotinic agonists and antagonists had little effect on induced postsynaptic responses, but that D-tubocurarine (D-TC), strychnine, kynurenic acid, and 2 kynurenic acidrelated antagonists, $\gamma$-D-glutamylglycinc $(\gamma-\mathrm{D}-\mathrm{GG})$ and $c i s-2$, 3-piperidine dicarboxylic acid (PDA), had marked effects on postsynaptic responses (Langdon and Freeman, 1986, 1987). These workers suggest that kainate-type receptors may mediate excitatory retinotectal transmission in this system.

In this study, we have characterized, in goldfish brain, the binding of a number of relatively selective radioligands for glutamate receptor subtypes. The distribution and density of the binding sites for each ligand was determined. In addition, the effect of eye removal on the number of binding sites in the contralateral optic tectum was investigated and compared to ${ }^{3} \mathrm{H}-(-)$ nicotine and ${ }^{125} \mathrm{I}-\alpha-\mathrm{Bgt}$.

\section{Materials and Methods}

Goldfish (Carassius auratus) were from Grassyfork Fisheries. ${ }^{3} \mathrm{H}-\mathrm{Kai}-$ nate $(3.6 \mathrm{Ci} / \mathrm{mmol})$ was from Amersham; ${ }^{3} \mathrm{H}$-AMPA $(26 \mathrm{Ci} / \mathrm{mmol}),{ }^{3} \mathrm{H}$ L-glutamate $(41$ and $52 \mathrm{Ci} / \mathrm{mmol}),{ }^{3} \mathrm{H}-\mathrm{PCP}(46.7 \mathrm{Ci} / \mathrm{mmol}),{ }^{3} \mathrm{H}-\mathrm{TCP}$ $(44.3 \mathrm{Ci} / \mathrm{mmol}),{ }^{3} \mathrm{H}-(-)$ nicotine $(60$ and $80 \mathrm{Ci} / \mathrm{mmol})$, and ${ }^{125} \mathrm{I}-\alpha-\mathrm{Bgt}$ (70-140 Ci/mmol) were obtained from New England Nuclear (Boston, MA). NMDA, 2-amino-4-phosphovalerate (APV), $\gamma$-D-glutamylglycine $(\gamma-\mathrm{D}-\mathrm{GG})$, and AMPA were from Cambridge Research Biochemicals (Atlantic Beach, NY). All other compounds and chemicals were obtained from Sigma Chemical Co. (St. Louis, MO).

Brain dissection. The intact brain was removed from ice-anesthetized goldfish and, in some cases, the major brain areas were separated by dissection on a clean petri dish. In enucleated fish, the brains were taken at various time points following eye removal, and the ipsilateral and contralateral optic tecta were teased free from the rest of the brain using fine forceps. The cortex and vagal lobes were then separated using the same technique and the remaining tissue was defined as cerebellum. Each of the dissected regions was immediately frozen in liquid nitrogen and stored at $-80^{\circ} \mathrm{C}$.

Tissue preparation. (1) "Glutamate-free" tissue preparation: A "glutamate-free" crude synaptic membrane fraction was prepared using a modification of the procedure described by Murphy et al. (1987). Tissue was homogenized in $0.32 \mathrm{M}$ sucrose at $0^{\circ} \mathrm{C}$ and centrifuged in a Beckman $\mathrm{JA}-21$ rotor at $1000 \times g$ for $10 \mathrm{~min}$ at $4^{\circ} \mathrm{C}$. The supernatant was collected and centrifuged at $20,000 \times g$ for $20 \mathrm{~min}$. The resultant pellet was resuspended in distilled water at $0^{\circ} \mathrm{C}$ and homogenized with a polytron (setting 6 for $30 \mathrm{sec}$ ). The suspension was then centrifuged for $20 \mathrm{~min}$ at $8000 \times g$ at $4^{\circ} \mathrm{C}$. The supernatant was removed and recentrifuged at $48,000 \times g$ for $15 \mathrm{~min}$. The pellet was resuspended in $50 \mathrm{~mm}$ Tris- $\mathrm{HCl}$, $\mathrm{pH} 7.4$, at $0^{\circ} \mathrm{C}$, rapidly frozen in liquid nitrogen, and allowed to thaw at room temperature. After thawing, the suspension was diluted to 15 $\mathrm{ml}$ and centrifuged at $48,000 \times \mathrm{g}$ for $15 \mathrm{~min}$. The pellet was resuspended in $2 \mathrm{ml}$ of Tris- $\mathrm{HCl}$, refrozen, and washed. The freeze-thaw wash cycle was repeated a total of 3 times. The tissue was then resuspended to a final concentration of approximately $300 \mathrm{mg} / \mathrm{ml}$, and $1 \mathrm{ml}$ aliquots dispensed into microcentrifuge tubes. The tissue was then centrifuged, the supernatant discarded, and the pellet stored frozen at $-80^{\circ} \mathrm{C}$ until use.

(2) "P2" tissue preparation: For routine ${ }^{3} \mathrm{H}-(-)$ nicotine and some ${ }^{3} \mathrm{H}-$ kainate and ${ }^{125} \mathrm{I}-\alpha$-Bgt binding, goldfish brain $\mathrm{P} 2$ membrane fractions were prepared as previously described (Henley and Oswald, 1986a) in either $50 \mathrm{~mm} 3-(N$-morpholino) propanesulfonic acid (MOPS)/NaOH, $1 \mathrm{~mm}$ EGTA, pH 7.4, or Ringer's saline $(80 \mathrm{~mm} \mathrm{NaCl}, 3.5 \mathrm{~mm} \mathrm{KCl}$, $10.6 \mathrm{~mm} \mathrm{Na}$ phosphate, $1.2 \mathrm{mM} \mathrm{MgCl}, 1.3 \mathrm{mM} \mathrm{CaCl}_{2}$, pH 7.4).

${ }^{3} \mathrm{H}$-AMPA binding assays. Frozen tissue was thawed in $1 \mathrm{ml}$ of Tris$\mathrm{HCl}, \mathrm{pH} 7.4$, and the suspension incubated at $37^{\circ} \mathrm{C}$ for $30 \mathrm{~min}$. The tissue was then washed 3 times by centrifugation in a minifuge and the pellets resuspended in Tris- $\mathrm{HCl}$ as appropriate. For routine experiments, tissue was resuspended to approximately $100 \mathrm{mg} / \mathrm{ml}$ original wet weight and the final tissue concentration in the binding assays was approximately $20 \mathrm{mg} / 0.5 \mathrm{ml}$. Aliquots of tissue, $200 \mu \mathrm{l}$, were incubated for 60 min on ice with ${ }^{3} \mathrm{H}$-AMPA ( $\alpha$-amino-3-hydroxy-5-methylisoxazolepropionate) (usually $10 \mathrm{~nm}$ final concentration) in either the presence or absence of $100 \mu \mathrm{M}$ cold AMPA. The chaotrope $\mathrm{KSCN}$ was also included in all incubations at a final concentration of $100 \mathrm{~mm}$. If $\mathrm{KSCN}$ was omitted, specific ${ }^{3} \mathrm{H}$-AMPA binding was dramatically reduced, as has previously been demonstrated in rat brain (Murphy et al., 1987). The reaction was terminated by addition of $3 \mathrm{ml}$ of ice-cold Tris- $\mathrm{HCl}$ buffer and rapid filtration under negative pressure on either Whatman GF/C or Schleicher and Schuell \#32 filters prewetted with $0.05 \%$ polyethylenimine (PEI) (Bruns et al., 1983). The filters were washed an additional 2 times with $3 \mathrm{ml}$ aliquots of Tris- $\mathrm{HCl}$ buffer and allowed to dry. The dry filters were then extracted with Amersham ACS aqueous scintillant, and the radioactivity measured.

${ }^{3} \mathrm{H}$-Kainate binding assays. "Glutamate-free" tissue was thawed, washed, and resuspended as described above. ${ }^{3} \mathrm{H}$-Kainate binding was determined essentially as previously reported in the P2 fraction of goldfish brain (Migani et al., 1985). Routinely, approximately $20 \mathrm{mg}$ wet weight of original tissue was incubated for $60 \mathrm{~min}$ on ice with $10 \mathrm{nM}$ ${ }^{3} \mathrm{H}$-kainate either in the presence or absence of $100 \mu \mathrm{M}$ cold kainate. The reaction was stopped and the amount of radioactivity specifically bound to the tissue was assessed by filtration, as described for ${ }^{3} \mathrm{H}$ AMPA. For experiments using the P2 fraction, the same protocol was followed except that Ringer's saline was substituted for Tris- $\mathrm{HCl}$ buffer.

${ }^{3} \mathrm{H}-\mathrm{L}$-Glutamate binding assays. ${ }^{3} \mathrm{H}-\mathrm{L}$-Glutamate binding was determined using a variety of techniques in order to establish a convenient and reliable assay.

1. Pellet assays. "Glutamate-free" tissue was incubated with ${ }^{3} \mathrm{H}-\mathrm{L}-$ glutamate in $50 \mathrm{~mm}$ Tris- $\mathrm{HCl}, \mathrm{pH} 7.4$, buffer for $1 \mathrm{hr}$ on ice in the presence or absence of excess cold L-glutamate ( $1 \mathrm{mM})$ in microcentrifuge tubes $(1.5 \mathrm{ml})$. The tubes were then centrifuged at $10,000 \times g$ for 15 min at $4^{\circ} \mathrm{C}$ and pellet assays performed as described by Krodel et al. (1979).

2. Filter assays. Filter assays using Millipore HAWP filters were carried out as previously detailed (Baudry and Lynch, 1981). "Glutamatefree" tissue was incubated in glass tubes with ${ }^{3} \mathrm{H}$-L-glutamate in icecold $50 \mathrm{~mm}$ Tris- $\mathrm{HCl}, \mathrm{pH} \mathrm{7.4,} \mathrm{buffer} \mathrm{for} 1 \mathrm{hr}$ on ice in the presence or absence of excess cold L-glutamate. The reaction was terminated by addition of $3 \mathrm{ml}$ of ice-cold Tris- $\mathrm{HCl}$ and filtration under negative pressure on IIAWP filters (soaked in bovine serum albumin). The tube and filter were rapidly rinsed $(10-15 \mathrm{sec})$ with a further $3 \mathrm{ml}$ of Tris$\mathrm{HCl}$ and the filters removed, dissolved in scintillation fluid, and the retained radioactivity determined. Filter assays on glass filters were performed exactly as described for HAWP filters, but Schleicher and Schuell \#32 filters were used.

${ }^{3} \mathrm{H}-\mathrm{PCP}$ and ${ }^{3} \mathrm{H}-\mathrm{TCP}$ binding assays. Both 1-(phenylcyclohexyl)piperidine $\left({ }^{3} \mathrm{H}-\mathrm{PCP}\right)$ and ${ }^{3} \mathrm{H}-\mathrm{TCP}$ failed to bind to the "glutamatefree" tissue preparation from goldfish brain using the same protocol as described for ${ }^{3} \mathrm{H}$-kainate, except that excess cold PCP $(100 \mu \mathrm{M})$ was used to determine nonspecific binding. ${ }^{3} \mathrm{H}$-TCP binding was also investigated 

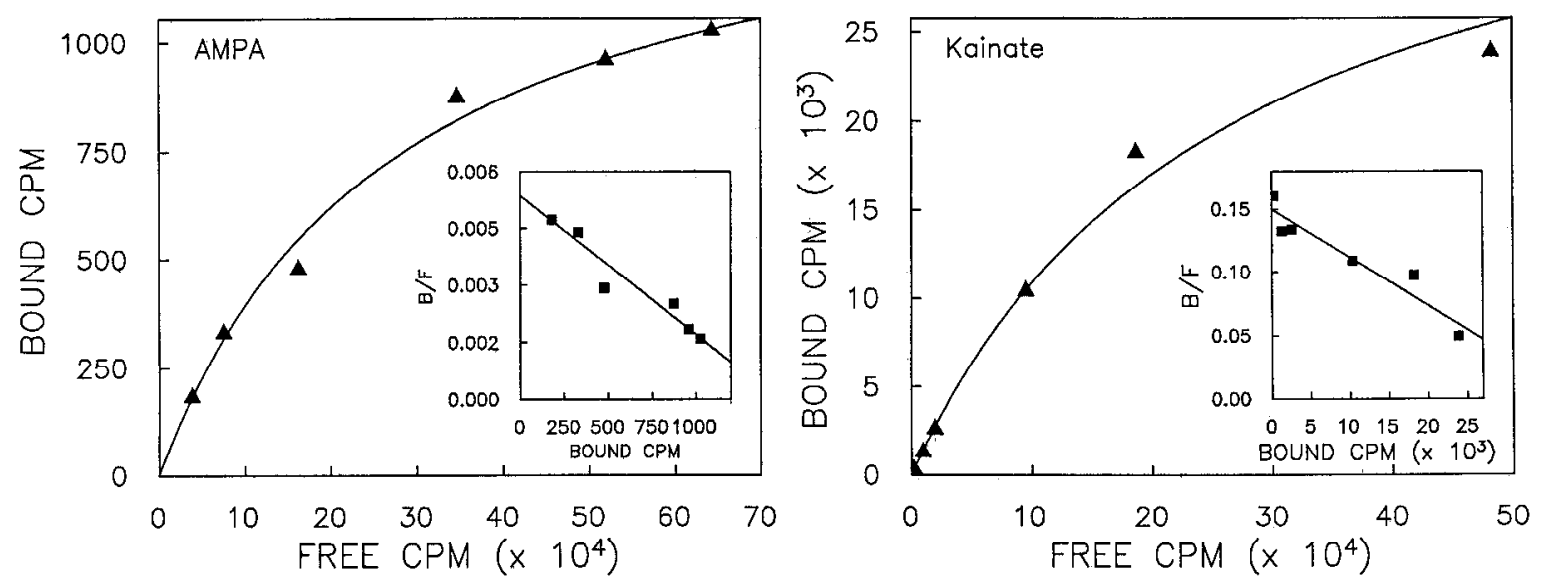

Figure 1. Representative saturation binding curves in Scatchard plots for ${ }^{3} \mathrm{H}-\mathrm{AMPA}$ and ${ }^{3} \mathrm{H}$-kainate. The mean $K_{\mathrm{d}} \mathrm{s}$ and $B_{\mathrm{max}} \mathrm{s}$ are given in Table 1. The experiments were performed as described in Materials and Methods.

in P2 membrane fractions using the same protocol except that Ringer's saline was used throughout.

${ }^{125} I-\alpha-B g$ t binding assays. ${ }^{125} I-\alpha$-Bgt binding assays were performed as previously described (Oswald and Freeman, 1979), except that "glutamate-free" tissue and Tris-HCl buffer were used. Briefly, the incubation conditions were exactly as described for the other ligands except that $2 \mathrm{nM}^{125} \mathrm{I}-\alpha$-Bgt was included in either the presence or absence of $1 \mathrm{~mm}$ carbamoylcholine and the tissue was incubated at room temperature. The reaction was terminated by addition of $3 \mathrm{ml}$ of Tris- $\mathrm{HCl}$ buffer at $0^{\circ} \mathrm{C}$ and filtration under negative pressure on Millipore EGWP or GVWP filters (soaked in bovine serum albumin). The filters were washed twice with $3 \mathrm{ml}$ of $\mathrm{Tris}-\mathrm{HCl}$ buffer and the retained radioactivity determined. When $\mathrm{P} 2$ fractions and Ringer's saline were used, the tissue was incubated with ${ }^{125} \mathrm{I}-\alpha$-Bgt for $8-14 \mathrm{hr}$ at $4^{\circ} \mathrm{C}$ to reach equilibrium. The samples were then filtered as described above and washed 3 times with ice-cold Ringer's saline.

${ }^{3} \mathrm{H}-(-)$ Nicotine binding assays. ${ }^{3} \mathrm{H}-(-)$ Nicotine assays were carried out using PEI prewetted glass filters, as previously described (Henley and Oswald, 1987), except that Ringer's saline was routinely used instead of MOPS/EGTA buffer.

Protein determinations. Protein determinations were performed using a modification of the Bradford method described by Spector (1978).

\section{Results}

The binding of ${ }^{3} \mathrm{H}-\mathrm{AMPA}$ and ${ }^{3} \mathrm{H}$-kainate to "glutamate-free" goldfish whole brain membrane preparations is shown in Figure 1. ${ }^{3} \mathrm{H}-(-)$ Nicotine, ${ }^{3} \mathrm{H}-\mathrm{PCP}$, and ${ }^{3} \mathrm{H}-\mathrm{TCP}$ failed to bind reproducibly to "glutamate-free" preparations. ${ }^{3} \mathrm{H}-\mathrm{TCP}$ binding to P2 membrane fractions (see Materials and Methods) was investigated, but the presence or absence of $1 \mathrm{~mm}$ L-glutamate produced no notable difference in the $K_{\mathrm{d}}$ or $B_{\max }$ or ${ }^{3} \mathrm{H}-\mathrm{TCP}$ binding (45 nM and $0.9 \mathrm{fmol} / \mathrm{mg}$ original wet weight of tissue respectively). The characterization of ${ }^{3} \mathrm{H}-\mathrm{PCP}$ and ${ }^{3} \mathrm{H}-\mathrm{TCP}$ was therefore not pursued further. ${ }^{3} \mathrm{H}-(-) \mathrm{Nicotine}$ binding was also investigated using a $\mathrm{P} 2$ membrane fraction. Both ${ }^{3} \mathrm{H}-(-)$ nicotine and ${ }^{125} \mathbf{I}-\alpha$-Bgt binding to goldfish brain membranes have been characterized previously (Oswald and Freeman, 1979; Henley and Oswald, 1987) and the results from this study agree well with these earlier reports. The binding characteristics of all of these ligands arc summarized in Tablc 1.

The inhibition of ${ }^{3} \mathrm{H}$-L-glutamate, ${ }^{3} \mathrm{H}$-AMPA, and ${ }^{3} \mathrm{H}$-kainate binding (final radioligand concentration of $10 \mathrm{nM}$ in each case) by a series of glutamatergic ligands is shown in Figure 2. Both L-glutamate and quisqualate displace each of the 3 glutamatergic ligands, but the calculated $K_{\mathrm{i}}$ for L-glutamate and quisqualate are different for each radioligand. Also, kynurenic acid is a more potent displacer of kainate than of AMPA or L-glutamate. Neither L-glutamate nor quisqualate, at a concentration of $1 \mathrm{~mm}$, displaced ${ }^{3} \mathrm{H}-(-)$ nicotine or ${ }^{125} \mathrm{I}-\alpha$-Bgt (data not shown).

An interesting aspect of the data shown in Tables 1 and 2 is that L-glutamate binds to approximately 10-fold fewer sites than kainate, that kainate does not inhibit ${ }^{3} \mathrm{H}-\mathrm{L}$-glutamate binding, and that L-glutamate inhibits ${ }^{3} \mathrm{H}$-kainate binding with a $K_{\mathrm{i}}$ almost 3 orders of magnitude higher than that for inhibition of ${ }^{3} \mathrm{H}$-L-glutamate binding. These data are consistent with the possibility that L-glutamate may bind with low affinity to the kainate site. If this were the casc, then, extrapolating from the $K_{\mathrm{i}}$ of L-glutamate inhibition of ${ }^{3} \mathrm{H}$-kainate binding $(107 \mu \mathrm{M})$, fewer than $0.01 \%$ of the total kainate sites would be occupied in the presence of $10 \mathrm{nM}{ }^{3} \mathrm{H}$-L-glutamate (less than $5 \mathrm{fmol} / \mathrm{mg}$ protein). If the remainder of the ${ }^{3} \mathrm{H}-\mathrm{L}$-glutamate sites have a $K_{\mathrm{d}}$ of approximately $300 \mathrm{nM}$, then approximately $3 \%$ of these sites would be occupied, or $150 \mathrm{fmol} / \mathrm{mg}$ protein. Therefore, assuming kainate binds only 10 its high-affinity site, only $3 \%$ of the ${ }^{3} \mathrm{H}-\mathrm{L}-$ glutamate sites should be displaced by kainate, which is consistent with the lack of inhibition reported in Table 2. These

\begin{tabular}{|c|c|c|}
\hline & $K_{\mathrm{d}}(\mathrm{nM})$ & $B_{\max }(\mathrm{pmol} / \mathrm{mg}$ protein $)$ \\
\hline${ }^{3} \mathrm{H}$-Kainate & $136.7 \pm 16.5$ & $62.7 \pm 2.3$ \\
\hline${ }^{3} \mathrm{H}$-AMPA & $25.5 \pm 2.9$ & $0.44 \pm 0.04$ \\
\hline${ }^{3} \mathrm{H}-\mathrm{L}-$ Glutamate & $323.3 \pm 76.2$ & $4.98 \pm 1.69$ \\
\hline${ }^{3} \mathrm{H}-(-)$ Nicotine & $9.3 \pm 4.1$ & $0.08 \pm 0.02$ \\
\hline${ }^{25} \mathrm{I}-\alpha-\mathrm{Bgt}$ & $0.08 \pm 0.01$ & $0.13 \pm 0.02$ \\
\hline
\end{tabular}

All the glutamatergic ligand and ${ }^{125} \mathrm{I}-\alpha$-Bgt binding experiments were carried out using "glutamate-free" tissue. ${ }^{3} \mathrm{H}-(-)$ Nicotine binding was characterized in less extensively washed (P2) tissue (see Materials and Methods). The data are the means and SEMs of 3-5 experiments. For all of the ligands except ${ }^{3} \mathrm{H}-\mathrm{L}-$ glutamate, the experiments were performed by incubating tissue with increasing concentrations of radioligand (constant specific activity) in the presence or absence of excess nonradiolabeled ligand to determine nonspecific binding. Saturation binding curves and Scatchard pluts were generated, and the $K_{\mathrm{d}}$ and $B_{\max }$ calculated. For ${ }^{3} \mathrm{H}-\mathrm{L}-$ glutatmate, because of its low binding affinity, experiments were carried out by varying the specific activity of the radioligand. A constant amount of ${ }^{3} \mathrm{H}-\mathrm{L}$-glutamate ( 5 pmol) was mixed with varying amounts of cold L-glutamate to reduce the specific activity of the ${ }^{3} \mathrm{H}$-L-glutamate incubated with tissue. From the resultant binding curves, pseudo-Scatchard plots were generated to estimate the $K_{\mathrm{d}}$ and $B_{\max }$. 


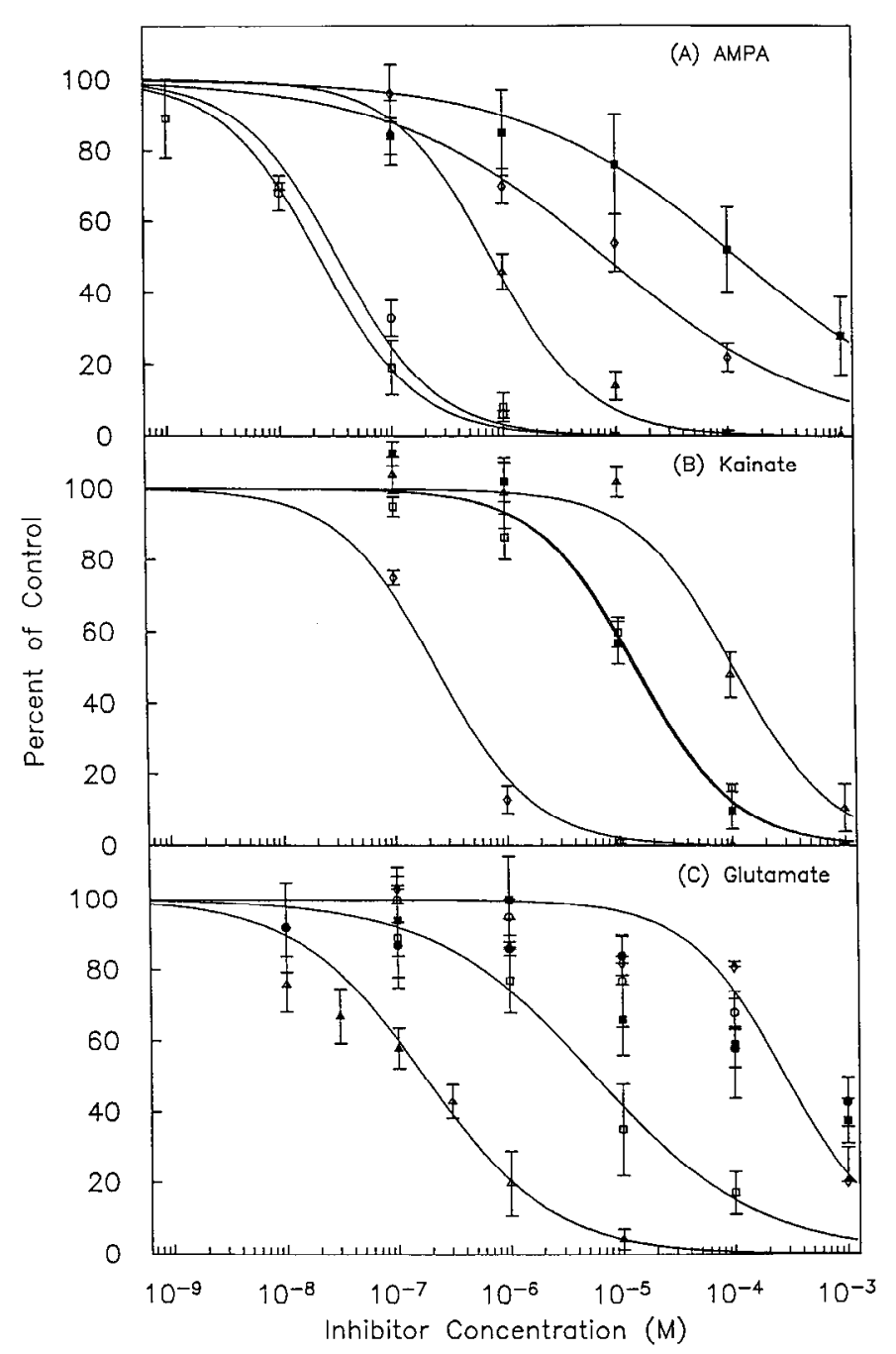

Figure 2. Effects of several glutamatergic ligands on the binding of $(A)$ ${ }^{3} \mathrm{H}$-AMPA, $(B){ }^{3} \mathrm{H}$-kainate, and $(C){ }^{3} \mathrm{H}$-L-glutamate. Only the inhibition curves for the most potent displacers are shown. The data are the means and SEMs of 3-4 separate experiments each with at least 5 different concentrations of inhibitor. $\triangle, \mathrm{L}$-Glutamate; NMDA; $\square$, quisqualate; $O$, AMPA; $\square$, kynurenic acid; $\diamond$, kainate. Control values are the amounts of radioligand bound in the absence of any inhibitor.
Table 2. $K_{i} \mathrm{~s}$ of various ligands on the binding of $10 \mathrm{nM}^{3} \mathrm{H}-\mathrm{L}-$ glutamate, $10 \mathrm{~nm}{ }^{3} \mathrm{H}$-kainate, and $10 \mathrm{nM}{ }^{3} \mathrm{H}$-AMPA to "glutamatefree" tissue (10-20 $\mathrm{mg}$ original wet weight of tissue per tube)

\begin{tabular}{lccc} 
& H-Kainate & ${ }^{3} \mathrm{H}$-AMPA & $\begin{array}{l}{ }^{3} \mathrm{H}-\mathrm{L}- \\
\text { Glutamate }\end{array}$ \\
\hline L-Glutamate & 107 & 0.79 & 0.32 \\
Quisqualate & 14.7 & 0.02 & 6.8 \\
NMDA & $>1000$ & $>1000$ & $\sim 1000$ \\
AMPA & 668 & 0.03 & $>1000$ \\
Kainate & 0.15 & 10 & $>1000$ \\
Kynurenic acid & 14 & 113 & 196 \\
$\gamma$-D-GG & $>1000$ & $>1000$ & $>1000$ \\
APV & 120 & $>1000$ & 88 \\
Carbamoylcholine & no decrease & no decrease & no decrease \\
$\alpha$-Bgt & no decrease & no decrease & no decrease
\end{tabular}

The data are the means of $3-4$ separate experiments, each with at least 5 different ligand concentrations sampled in duplicate. The $K_{i} \mathrm{~S}$ (in $\mu \mathrm{M}$ ) were calculated from the observed $\mathrm{IC}_{50} \mathrm{~s}$ using the equation $K_{\mathrm{i}}=\mathrm{IC}_{50} /\left(1+[\mathrm{L}] / K_{\mathrm{d}}\right)$ (see Cheng and Prussof, 1973).

data are also consistent with the lower number of sites for ${ }^{3} \mathrm{H}$ L-glutamate than for ${ }^{3} \mathrm{H}$-kainate in that the $B_{\max }$ extrapolated from $10 \mathrm{~nm}{ }^{3} \mathrm{H}$-L-glutamate would not detect the kainate sites because the affinity of L-glutamate for these sites would be far too low.

The regional distribution of binding sites for each of the ligands in goldfish brain is shown in Table 3. The brains were dissected into 4 main regions: the cortex, the optic tecta, the cerebellum and associated midbrain, and the vagal lobes. In membrane preparations from the 4 brain areas, ${ }^{3} \mathrm{H}-(-)$ nicotine and ${ }^{125} \mathrm{I}-\alpha$-Bgt differed slightly in their relative distribution. For ${ }^{3} \mathrm{H}-(-)$ nicotine, assessed in a $\mathrm{P} 2$ preparation, the highest percentage of binding sites was found in the optic tecta ( $40 \%$ of total) and the lowest in the cerebellum (9\% of total); for ${ }^{125} \mathrm{I}-\alpha$ Bgt, assessed in the "glutamate-free" preparation, the highest percentage of sites was present in the vagal lobes (35\% of total) and the lowest in the cerebellum (12\% of total).

${ }^{3} \mathrm{H}$-AMPA, L-glutamate-displaceable ${ }^{3} \mathrm{H}$-L-glutamate, and NMDA-displaceable ${ }^{3} \mathrm{H}$-L-glutamate binding all had very similar distributions in "glutamate-free" preparations that differed from that of ${ }^{3} \mathrm{H}-(-)$ nicotine and ${ }^{125} \mathrm{I}-\alpha$-Bgt. The cortex possessed the most binding sites ( $36-40 \%$ of total) and the cerebellum the least $\left(9-14 \%\right.$ of total). The relative binding distribution of ${ }^{3} \mathrm{H}$ -

Table 3. Regional distribution of ligand binding sites in goldfish brain

\begin{tabular}{lcccc} 
& \multicolumn{1}{c}{ CX } & OT & CB & VL \\
\hline${ }^{3}$ H-L-Glutamate & $9.9 \pm 1.1$ & $7.9 \pm 0.6$ & $4.0 \pm 0.3$ & $6.1 \pm 0.8$ \\
${ }^{3} \mathrm{H}-\mathrm{L}-$ Glutamate (NMDA) & $5.0 \pm 1.1$ & $4.7 \pm 0.5$ & $1.9 \pm 0.4$ & $3.7 \pm 0.8$ \\
${ }^{3} \mathrm{H}-$ Kainate & $44.6 \pm 7.3$ & $80.5 \pm 0.4$ & $130.2 \pm 0.7$ & $63.2 \pm 2.8$ \\
${ }^{3} \mathrm{H}-$ AMPA & $0.86 \pm 0.09$ & $0.49 \pm 0.03$ & $0.21 \pm 0.03$ & $0.63 \pm 0.03$ \\
${ }^{3} \mathrm{H}-(-)$ Nicotine & $51.1 \pm 3.2$ & $116.8 \pm 7.5$ & $27.2 \pm 1.3$ & $96.8 \pm 1.1$ \\
${ }^{125} \mathrm{I}-\alpha$-Bgt & $154.2 \pm 11.6$ & $145.3 \pm 9.4$ & $64.8 \pm 1.2$ & $191.7 \pm 1.3$ \\
\hline
\end{tabular}

All of the ligands were used at a final concentration of $10 \mathrm{~nm}$. The brains were removed and dissected as described in Materials and Methods. The amount of tissue varied depending on the brain region investigated, but was in the range of $0.1-1 \mathrm{mg}$ protein/tube (determined using Bradford protein assays). The results are expressed in $\mathrm{pmol} / \mathrm{mg}$ protein for the glutamatergic ligands $\left({ }^{3} \mathrm{H}-\mathrm{L}\right.$-glutamate, ${ }^{3} \mathrm{H}-$-kainate, and $\left.{ }^{3} \mathrm{H}-\mathrm{AMPA}\right)$ and $\mathrm{fmol} / \mathrm{mg}$ protein for the cholinergic ligands ${ }^{3} \mathrm{H}-(-)$ nicotine and ${ }^{125} \mathrm{I}-\alpha$-Bgt). Brain regions: CX, cortex; OT, optic tecta; CB, cerebellum; and VL, vagal lobes. All of the experiments were carried out on "glutamate-free" tissue, except for the " $\mathrm{H}-(-$ )nicotine experiments, which were performed using the P2 tissue preparation (see Materials and Methods). The data are the means and SEMs of 3-4 determinations. 
kainate in "glutamate-free" preparations differed substantially from that of all the other ligands investigated, with most sites present in the cerebellum ( $41 \%$ of total), and fewest in the cortex (14\% of total).

A time course showing the effects of enucleation on the binding of ${ }^{3} \mathrm{H}$-kainate, ${ }^{3} \mathrm{H}-(-)$ nicotine, and ${ }^{125} \mathrm{I}-\alpha-\mathrm{Bgt}$ binding in the contralateral tectum is shown in Figure 3. Single-time-point experiments were also carried out to determine whether eye removal resulted in any alteration in the number of ${ }^{3} \mathrm{H}$-AMPA, L-glutamate-displaceable ${ }^{3} \mathrm{H}$-L-glutamate, NMDA-displaceable ${ }^{3} \mathrm{H}$-L-glutamate or ${ }^{3} \mathrm{H}$-TCP binding sites in the contralateral tectum. Following a survival pcriod of $14 \mathrm{~d}$, no change (100 \pm $8 \%$, expressed as a fraction of the number of binding sites in the ipsilateral tectum) in the number of binding sites for any of these ligands was observed. ${ }^{3} \mathrm{H}$-Kainate binding was investigated in greater detail because previously reported electrophysiological experiments in the goldfish retinotectal system have suggested that the kainate receptor may mediate retinotectal transmission (Langdon and Freeman, 1987). Over the time period investigated, no marked alteration in the number of ${ }^{3} \mathrm{H}$ kainate binding sites in the contralateral tectum was observed following eye removal. Both ${ }^{3} \mathrm{H}-(-)$ nicotine and ${ }^{125} \mathrm{I}-\alpha$-Bgt binding sites in the contralateral tectum were reduced by $40-50 \%$ following eye removal. The time course of the loss was similar for both ligands, with the maximal decrease in binding sites being reached at approximately $7 \mathrm{~d}$ following enucleation.

\section{Discussion}

The main observations presented in this report are as follows: (1) The total population of ${ }^{3} \mathrm{H}-\mathrm{L}$-glutamate binding sites appear to be comprised of at least 3 subtypes of binding sites: kainateselective, AMPA-selective and NMDA-selective. The kainate and AMPA sites were directly measurable using tritiated ligands, but the NMDA binding sites were only discernible by displacing ${ }^{3}$ II-L-glutamate binding with cold NMDA. (2) Approximately an order of magnitude more ${ }^{3} \mathrm{H}$-kainate binding sites than ${ }^{3} \mathrm{H}$ I-glutamate binding sites were detected. (3) The rank order of potency of various glutamatergic displacers differed for the 3 radioligands investigated. (4) Eye removal resulted in a decrease in ${ }^{3} \mathrm{H}-(-)$ nicotine and ${ }^{125} \mathrm{I}-\alpha$-Bgt binding sites in the contralateral optic tectum but not in ${ }^{3} \mathrm{H}$-kainate, ${ }^{3} \mathrm{H}$-L-glutamate, or ${ }^{3} \mathrm{H}$ AMPA binding sites. (5) The regional distribution of ${ }^{3} \mathrm{H}$-kainate binding sites differed markedly from the distribution of the other ligands investigated.

Kainate is a well-characterized neurostimulant that displays toxic effects at high concentrations (McGeer et al., 1978; Fuxe et al., 1983). Specific kainate binding sites have been previously demonstrated in goldfish brain preparations (Migani et al., 1985), and comparative data have indicated that kainate binding sites are present in far greater numbers in lower vertebrates, such as fish and amphibia, than in higher vertebrates, such as rats and pigeons (Simon et al., 1976; London et al., 1980; Migani et al., 1985). Excitatory responses to kainate are relatively insensitive to antagonism by NMDA antagonists or by L-glutamate diethyl ester (GDEE). In this study, however, we demonstrate that kynurenic acid is approximately an order of magnitude more potent at displacing ${ }^{3} \mathrm{H}$-kainate binding than at displacing ${ }^{3} \mathrm{H}-\mathrm{L}-\mathrm{glu}-$ tamate or ${ }^{3} \mathrm{H}$-AMPA.

Migani et al. (1985) reported 2 classes of ${ }^{3} \mathrm{H}$-kainate binding sites in the $\mathrm{P} 2$ fraction from goldfish brain, the main population having a $B_{\max }$ of approximately $139 \mathrm{pmol} / \mathrm{mg}$ protein and a $K_{\mathrm{d}}$ of approximately $50 \mathrm{~nm}$. In this study, only one class of ${ }^{3} \mathrm{H}$ -

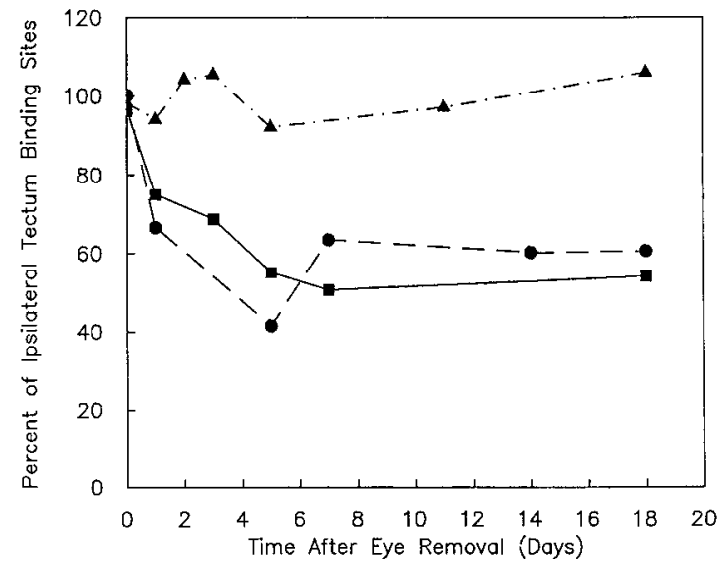

Figure 3. Time course of loss of ${ }^{3} \mathrm{H}$-kainate $(\boldsymbol{\Delta}),{ }^{3} \mathrm{H}-(-)$ nicotine $(\bullet)$, and ${ }^{125} 1-\alpha-\operatorname{Bgt}(\varpi)$ binding sites from the contralateral tecta. The optic tecta were dissected from enucleated fish after the survival times indicated, and the number of binding sites (expressed as either sites $/ \mathrm{mg}$ wet weight of tissue or site/mg of protein) was determined. Each time point represents the mean of duplicate determinations using the ipsilateral and contralateral tecta pooled from 3-8 fish. The data are plotted as the percentages of sites in the contralateral tectum compared to those present in the control ipsilateral tectum (100\%).

kainate binding sites was detected. Using Tris- $\mathrm{HCl}$ and the "glutamate-free" tissue preparation, ${ }^{3} \mathrm{H}$-kainate bound with a $B_{\max }$ of approximately $63 \mathrm{pmol} / \mathrm{mg}$ protein and a $K_{\mathrm{d}}$ of approximately $137 \mathrm{~nm}$. The differences between the results reported by Migani et al. (1985) and those presented here may in part be explained by the more rigorous washing procedures used in this study, resulting in the loss of some binding sites and a decrease in affinity. However, under conditions similar to those reported by Migani et al. (1985), using P2 tissue preparations and Ringer's saline, we also detected only a single binding site $\left(B_{\max }-44\right.$ $\mathrm{pmol} / \mathrm{mg}$ protein and $K_{\mathrm{d}}=86 \mathrm{nM}$; mean of 2 experiments, each carried out in duplicate).

The rank order of potency of various compounds in displacing ${ }^{3} \mathrm{H}$-kainate binding from goldfish brain in this report agrees well with that of Migani et al. (1985). Of the competitive ligands used in both studies, the order of potency was kainate $>$ quisqualate $=$ kynurenic acid (this report only) $>$ L-glutamate $>$ NMDA. The concentrations of each compound needed to inhibit $50 \%$ of the binding were also similar, except for kainate, which was found to reduce ${ }^{3} \mathrm{H}$-kainate binding half-maximally at $38 \mathrm{nM}$ in the earlier investigation but at approximately 240 nM ("glutamate-free" tissue in Tris- $\mathrm{HCl}$ buffer) in this study. This difference in the potency of cold kainate at displacing ${ }^{3} \mathrm{H}$ kainate binding is consistent with the lower affinity measured in our tissue preparation.

${ }^{3} \mathrm{H}-\mathrm{L}-$ Glutamate binding has also been extensively investigated, but not, to our knowledge, in goldfish brain. Most studies have focused on rat brain, where a wide range of $K_{\mathrm{d}}$ and $B_{\max }$ values have been reported. The rank-order potency for compounds in inhibiting ${ }^{3} \mathrm{H}$-L-glutamate binding in rat is L-glutamate $>=$ quisqualate $>$ APV (for review, see Foster and Fagg, 1984). The same order of potency of these compounds was observed in this study. NMDA displaces a fraction of binding in a dose-dependent manner, and at $1 \mathrm{~mm} 50-60 \%$ of the ${ }^{3} \mathrm{H}$ L-glutamate binding is inhibited. These data are consistent with the proposal that a proportion of the total ${ }^{3} \mathrm{H}-\mathrm{L}$-glutamate binding sites represents NMDA-type receptors, and quantitatively 
similar NMDA-displacement results have been demonstrated in rat brain (Fagg and Matus, 1984).

NMDA receptors are the best-characterized electrophysiologically, but the least-well-studied using ligand binding techniques, owing to the low affinity of NMDA receptor ligands. ${ }^{3} \mathrm{H}-\mathrm{NMDA}$ binding studies have yielded no reproducible results (for review, see Foster and Fagg, 1984). More recently, the phencyclidines, PCP and its analogs TCP and tiletamine, have been proposed as selective markers for NMDA receptors (Anis et al., 1983; Thomson et al., 1985). Tiletamine blocks NMDA-, but not quisqualate-evoked depolarizations in CA1 pyramidal cells, and PCP inhibits the NMDA-evoked release of ${ }^{3} \mathrm{H}-\mathrm{ACh}$ from striatum (Lehman and Scatton, 1982). PCP and TCP binding is potentiated in the presence of L-glutamate and NMDA in a dose-dependent fashion and there is a marked concordance in the distribution of TCP and NMDA binding sites, assessed autoradiographically, in rat brain (Maragos et al., 1986). These data suggest that PCP and its analogs may bind to and block the ion channel associated with the NMDA-type receptor. In this study, however, we were unable to reproducibly demonstrate ${ }^{3} \mathrm{H}-\mathrm{PCP}$ or ${ }^{3} \mathrm{H}-\mathrm{TCP}$ binding to "glutamate-free" tissue preparations, or to "glutamate-free" tissue when L-glutamate was added back to the preparation. In the P2 membrane fraction, the presence or absence of $1 \mathrm{mM} \mathrm{L-glutamate}$ had no apparent effect on ${ }^{3} \mathrm{H}$-TCP binding, and the number of ${ }^{3} \mathrm{H}$-TCP binding sites in the contralateral tectum did not appear to be reduced following eye removal. Experiments using this radioligand were therefore not further pursued in this study.

Quisqualate receptors in rat brain have recently been investigated using ${ }^{3} \mathrm{H}$-AMPA (Honore and Nielson, 1985; Murphy et al., 1987). AMPA is a heterocyclic analog of L-glutamate that is a potent stimulant in mammalian spinal neurons, whose action is blocked by the quisqualate receptor antagonist GDEE (Krogsgaard-Larson et al., 1980). With a filtration assay the rank order of potency of various compounds at displacing ${ }^{3} \mathrm{H}-\mathrm{AMPA}$ in rat brain has been reported to be quisqualate > AMPA > L-glutamate (Murphy et al., 1987). Exactly the same order was observed in our study at slightly greater, but relatively similar, concentrations. Workers also report that inclusion of $100 \mathrm{~mm}$ KSCN greatly enhanced the number of detectable ${ }^{3} \mathrm{H}$-AMPA binding sites. The apparent $K_{\mathrm{d}}$ and $B_{\max }$ values for ${ }^{3} \mathrm{H}$-AMPA in freeze-thawed rat membranes in the presence of KSCN were approximately $71 \mathrm{nM}$ and $1.1 \mathrm{pmol} / \mathrm{mg}$ protein, respectively, when measured using a filtration assay. In similarly isolated goldfish brain preparations in the presence of KSCN we found ${ }^{3} \mathrm{H}$-AMPA had a $K_{\mathrm{d}}$ of approximately $25 \mathrm{nM}$ and a $B_{\max }$ of approximately $0.4 \mathrm{pmol} / \mathrm{mg}$ protein.

The regional distribution of each of the glutamatergic ligands was compared to the distribution of ${ }^{3} \mathrm{H}-(-)$ nicotine and ${ }^{125} \mathrm{I}-\alpha-$ Bgt. ${ }^{3} \mathrm{H}$-AMPA, total ${ }^{3} \mathrm{H}$-L-glutamate, and NMDA-displaceable ${ }^{3} \mathrm{H}-\mathrm{L}-\mathrm{glutamate}$ binding all had similar distributions. The relative distribution of these ligand binding sites was as follows: cortex, 36-40\%; optic tecta, 23-28\%; cerebellum, 9-14\%; and vagal lobes, $21-29 \%$. The binding distribution of ${ }^{3} \mathrm{H}$-kainate differed markedly from all of the other ligands investigated: cortex, $14 \%$; optic tecta, $25 \%$; cerebellum, $41 \%$; and vagal lobes, $20 \%$. The major differences between the regional distribution of binding sites for ${ }^{3} \mathrm{H}$-kainate and the other glutamatergic ligands used suggest that ${ }^{3} \mathrm{H}$-kainate labels a protein that is not detectable with the other ligands. As demonstrated in the results, however, ${ }^{3} \mathrm{H}$-kainate binding can be totally blocked by L-glu- tamate. Taken together, these data suggest that the kainate binding site may correspond to a very-low-affinity L-glutamate site that was not detectable in ${ }^{3} \mathrm{II}-\mathrm{L}$-glutamate binding experiments.

The binding sites for ${ }^{3} \mathrm{H}-(-)$ nicotine and ${ }^{125} \mathrm{I}-\alpha$-Bgt differed slightly in their relative distribution. For ${ }^{3} \mathrm{H}-(-)$ nicotine, the distribution of binding sites (expressed as the percentage of total binding) was cortex, $17 \%$; optic tecta, $40 \%$; cerebellum, $9 \%$; vagal lobes, $34 \%$; while for ${ }^{125} \mathrm{I}-\alpha$-Bgt, the distribution was cortex, $28 \%$; optic tecta, $26 \%$; cerebellum, $12 \%$; vagal lobes, $35 \%$. Although no absolute comparisons can be made from these results, the slightly different distribution of each ligand suggests that a proportion of the ${ }^{3} \mathrm{H}-(-)$ nicotine and ${ }^{125} \mathrm{I}-\alpha$-Bgt binding sites are located in different brain regions, suggesting that at least one class of binding sites for each ligand is probably located on separate proteins. The marked overall similarity in the distribution of each of these cholinergic ligands, however, is consistent with the proposal that a fraction of the ${ }^{3} \mathrm{H}-(-)$ nicotine and ${ }^{125} \mathrm{I}-\alpha-\mathrm{Bgt}$ binding sites may be colocalized on the same protcin (Henlcy and Oswald, 1987).

Enucleation resulted in a dramatic reduction in the number of ${ }^{3} \mathrm{H}-(-)$ nicotine and ${ }^{125} \mathrm{I}-\alpha$-Bgt binding sites in the contralateral tectum compared to the ipsilateral tectum. The time course and extent of loss of the binding sites for each of these ligands were similar and the ${ }^{125} \mathrm{I}-\alpha-\mathrm{Bgt}$ binding data are consistent with previously reported results (Oswald et al., 1980). The ${ }^{3} \mathrm{H}-(-)$ nicotine binding data also confirm previously reported single-timepoint results (Henley and Oswald, 1987). Detailed examination of the time course of ${ }^{3} \mathrm{H}-(-)$ nicotine binding following enucleation suggests that ${ }^{3} \mathrm{H}-(-)$ nicotine sites appear to be lost in parallel to the loss of ${ }^{125} \mathrm{I}-\alpha$-Bgt binding sites. We have previously provided evidence, using monoclonal antibodies, to suggest that the ${ }^{125} \mathrm{I}-\alpha$-Bgt binding sites are located presynaptically (Henley et al., 1986b). The similarity of the profiles for the loss of ${ }^{3} \mathrm{H}$ $(-)$ nicotine and ${ }^{125} \mathrm{I}-\alpha$-Bgt binding sites, and the distribution data presented in this study, along with biochemical evidence previously reported (Henley and Oswald, 1987), suggest that a fraction of the ${ }^{3} \mathrm{H}-(-)$ nicotine and ${ }^{125} \mathrm{I}-\alpha-\mathrm{Bgt}$ binding sites may be located on the same, or very closely related, proteins. It therefore seems probable that the ${ }^{3} \mathrm{H}-(-)$ nicotine binding sites lost in the contralateral tectum following enucleation may also be presynaptic in location.

Eye removal had little effect on the number of ${ }^{3} \mathrm{H}$-kainate, ${ }^{3} \mathrm{H}$-AMPA, NMDA-displaceable ${ }^{3} \mathrm{H}$-L-glutamate, and L-glutamate-displaceable ${ }^{3} \mathrm{H}$-L-glutamate binding sites in the contralateral tecta. Langdon and Freeman (1987), using electrophysiological techniques, have demonstrated that kynurenic acid is a potent inhibitor of postsynaptic responses in the goldfish optic tectum. In this study, we show that kynurenic acid displaces ${ }^{3} \mathrm{H}$-kainate binding at lower concentrations than were necessary to displace ${ }^{3} \mathrm{H}$-AMPA and ${ }^{3} \mathrm{H}$-L-glutamate, but that ${ }^{3} \mathrm{H}$-kainate binding sites are not lost following enucleation. These data do not rule out the involvement of glutamatergic receptors in the goldfish retinotectal system, but if the endogenous ligand for these receptors were the primary visual neurotransmitter, some regulation of the number of binding sites after eye removal, and presumably the inhibition of neurotransmitter release, may have been expected.

\section{References}

Anis, N. A., S. C. Berry, N. R. Burton, and D. Lodge (1983) The dissociative anaesthetics ketamine and phencyclidine selectively re- 
duce excitation of central mammalian neurones by NMDA. Br. J. Pharmacol. 79: 565-575.

Barth, R., and D. Felix (1974) Influence of GABA and glycine and their antagonists on inhibitory mechanisms of pigeon optic tectum. Brain Res. 80: 532-537.

Baudry, M., and G. Lynch (1981) Characterization of two $\left[{ }^{3} \mathrm{H}\right]$ glutamate binding sites in rat hippocampal membranes. J. Neurochem. 36:811820.

Beart, P. M. (1976) An evaluation of L-glutaniate as the transmitter released from optic nerve terminals in pigeon. Brain Res. 110: 99114.

Bruns, R. F., K. Lawson-Wendling, and T. A. Pugsley (1983) A rapid filtration assay for soluble receptors using polyethyleninime-treated filters. Anal. Biochem. 132: 74-81.

Cheng, Y. C., and W. H. Prussoff (1973) Relationship between the inhibition constant $(\mathrm{Ki})$ and the concentration of inhibitor which causes 50 percent inhibition (IC.50) of an enzymatic reaction. Biochem. Pharmacol. 129: 3099-3108.

Collingridge, G. L. S., S. J. Kehl, and H. McLennon (1983) Excitatory amino acids in synaptic transmission in the Schaffer-commissural pathway of the rat hippocampus. J. Physiol. (Lond.) 334: 33-46.

Davies, J., and J. C. Watkins (1983) Role of excitatory amino acid receptors in mono- and polysynaptic excitation in the cat spinal cord. Exp. Brain Res. 49: 280-290.

Fagg, G. E., and A. I. Matus (1984) Selective association of NMDA and quisqualate types of L-glutamate receptor with brain postsynaptic densities. Proc. Natl. Acad. Sci. USA 81: 6876-6880.

Foster, A. C., and G. Fagg (1984) Acidic amino acid binding sites in mammalian neuronal membranes: Their characteristics and relationship to synaptic receptors. Brain Res. Rev. 7: 103-164.

Freeman, J. A., J. T. Schmidt, and R. E. Oswald (1980) Effect of $\alpha$-bungarotoxin in retinotectal transmission in goldfish and toad. Neuroscience 5: 929-942.

Fuxe, P., P. Roberts, and R. Schwartz (1983) Excitotoxins, Macmillan, London.

Henke, H., T. M. Schenker, and M. Cuenod (1976) Uptake of neurotransmitter candidates by pigeon optic tectum. J. Neurochem. 26: 131-134.

Henley, J. M., and R. E. Oswald (1987) Two distinct (-)nicotine binding sites in goldfish brain: Identification and characterization of putative neuronal nicotinic acetylcholine receptor subtypes. J. Biol. Chem. 262: 6691-6698.

Henley, J. M., and R. E. Oswald (1988) Solubilization and characterization of kainate receptors from goldfish brain. Biochim. Biophys. Acta 937: 103-111.

Henley, J. M., M. Mynlieff, J. M. Lindstrom, and R. E. Oswald (1986a) Interaction of monoclonal antibodies to electroplaque acetylcholine receptors with the $\alpha$-bungarotoxin binding site of goldfish brain. Brain Res. 364: 405-408.

Henley, J. M., J. M. Lindstrom, and R. E. Oswald (1986b) Acetylcholine receptor synthesis in retina and transport to the optic tectum in goldfish. Science 232: 1627-1629.

Hicks, T. P., J. G. Hall, and H. McLennon (1978) Ranking of excitatory amino acids by the antagonists glutamic acid diethyl ester and D- $\alpha$-aminoadipic acid. Can. J. Physiol. Pharmacol. 56: 901-906.

Honore, T., and M. Nielsen (1985) Complex structure of quisqualatesensitive glutamate receptors in rat cortex. Neurosci. Lett. 54: 27-32.

Krodel, E. K., R. A. Beckman, and J. B. Cohen (1979) Identification of a local anesthetic binding site in nicotinic post-synaptic membranes isolated from Torpedo marmorata electric tissue. Mol. Pharmacol. 15: 294-312.

Krogsgaard-Larsen, P., T. Honore, J. J. IIansen, D. R. Curtis, and D. Lodge (1980) New class of glutamate agonist structurally related to ibotenic acid. Nature 284: 64-66.
Langdon, R. B., and J. A. Freeman (1986) Antagonists of glutamatergic neurotransmission block retinotectal transmission in goldfish. Brain Res. 398: 169-174.

Langdon, R. B., and J. A. Freeman (1987) Pharmacology of retinotectal transmission in the goldfish: Effects of nicotinic ligands, strychnine and kynurenic acid. J. Neurosci. 7: 760-773.

Lehman, J., and B. Scatton (1982) Excitatory amino acid receptor mediated release of $\left[{ }^{3} \mathrm{H}\right]$ acetylcholine from striatal slices of the rat: Effect of magnesium and pharmacological characteristics. Brain Res. 252: 77-89.

London, E. D., N. Klemm, and J. T. Coyle (1980) Phylogenetic distribution of $\left[{ }^{3} \mathrm{H}\right]$ kainic acid receptor binding sites in neuronal tissue. Brain Res. 192: 463-476.

Maragos, W. F., D. C. M. Chu, J. T. Greeamyre, J. B. Penney, and A. B. Young (1986) High correlation between the localization of $\left[{ }^{3} \mathrm{H}\right] \mathrm{TCP}$ binding and NMDA receptors. Eur. J. Pharmacol. 123: 173-174.

Mayer, M. L., and G. I. Westbrook (1987) The physiology of excitatory amino acids in the vertebrate central nervous system. Prog. Neurobiol. 28: 197-276.

McGecr, E. G., J. W. Olney, and P. L. McGeer (1978) Kainic Acid as a Tool in Neurobiology, Raven, New York.

Migani, P., M. Virgili, A. Constestabile, A. Poli, L. Villani, and O. Barnabei (1985) [ $\left.{ }^{3} \mathrm{H}\right]$ Kainic acid binding sites in the synaptosomalmitochondrial (P2) fraction from goldfish brain. Brain Res. 361: 3645.

Murphy, D. E., E. W. Snowhill, and M. Williams (1987) Characterization of quisqualate recognition sites in rat brain tissue using [ $\left.{ }^{3} \mathrm{H}\right] \mathrm{AMPA}$ and the filtration assay. Neurochem. Res. 12:771-777.

Oswald, R. E., and J. A. Freeman (1979) Characterization of the nicotinic acetylcholine receptor isolated from goldfish brain. J. Biol. Chem. 254: 3419-3426.

Oswald, R. E., J. T. Schmidt, J. J. Norden, and J. A. Freeman (1980) Localization of $\alpha$-bungarotoxin binding sites in the goldfish retinotectal projection. Brain Res. 187: 113-127.

Ricciuti, A. J., and E. R. Gruberg (1985) Nucleus isthmus provides most tectal choline acetyltransferase in the frog Rana pipiens. Brain Res. 341: 399-402.

Roberts, P. J., and R. A. Yates (1976) Tectal deafferentation in the frog: Selective loss of L-glutamate and gamma-aminobutyrate. Neuroscience $1: 371-374$.

Schecter, N., A. Francis, D. G. Deutsch, and M. S. Gazzaniga (1979) Recovery of tectal nicotinic cholinergic receptor sites during optic nerve regeneration. Brain Res. 166: 57-64.

Schmidt, J. T., and J. A. Freeman (1980) Electrophysiological evidence that retinotectal transmission in goldfish is nicotinic cholinergic. Brain Res. 187: 129-142.

Schwartz, M., D. Axelrod, E. L. Feldman, and B. W. Agranoff (1980) Histological localization of binding sites of $\alpha$-bungarotoxin and of antibodies specific to acetylcholine receptors in goldfish optic nerve and tectum. Brain Res. 194: 171-180.

Simon, J. R., J. F. Contrera, and M. J. Kuhar (1976) Binding of $\left[{ }^{3} \mathrm{H}\right]$ kainate, an analogue of L-glutamate to brain membranes. J. Neurochem. 26: 141-147.

Snell, L. D., and K. M. Johnson (1985) Antagonism of NMDA induced transmitter release in rat striatum by phencyclidine-like drugs and its relationship to turning behavior. J. Pharmacol. Exp. Ther. 235: 5057.

Spector, T. (1978) Refinement of the Coomasie blue method of protein quantitation. Anal. Biochem. 86: 142-146.

Thomson, A. M., D. C. West, and D. Lodge (1985) An NMDA receptor mediated synapse in rat cerebral cortex: A site of action of ketamine? Nature 313: 479-481.

Watkins, J. C., and R. H. Evans (1981) Excitatory amino acid transmitters. Annu. Rev. Pharmacol. Toxicol. 21: 165-204. 